\title{
Open Innovation Management of Thai Auto Parts Manufacturer
}

\author{
Poramet Eamurai $^{1}$, Napaporn Khantanapha1, Rapeepun Piriyakul ${ }^{2}$ \\ ${ }^{1}$ Graduate School of Business Administration, Southeast Asia University, Bangkok, Thailand \\ ${ }^{2}$ Faculty of Science, Ramkhamhaeng University, Bangkok, Thailand \\ Email: i_poramet@hotmail.com, napakhan93@gmail.com,rapepunnight@yahoo.com
}

How to cite this paper: Eamurai, P., Khantanapha, N. and Piriyakul, R. (2019) Open Innovation Management of Thai Auto Parts Manufacturer. Open Journal of Business and Management, 7, 502-518. https://doi.org/10.4236/ojbm.2019.72034

Received: January 31, 2019

Accepted: March 17, 2019

Published: March 20, 2019

Copyright () 2019 by author(s) and Scientific Research Publishing Inc. This work is licensed under the Creative Commons Attribution International License (CC BY 4.0).

http://creativecommons.org/licenses/by/4.0/ (c) () Open Access

\begin{abstract}
This research aimed to study the application of knowledge to create open innovation of Thai automotive parts manufacturers. Data collection was conducted by using an in-depth interview form that was developed by setting interview topics and open-ended questions, including a small-group meeting of experts in the automotive industry to test and revise the interview form. According to the study, it was found that a problem of the innovation of Thai automotive parts manufacturers today was concerned with a lack of knowledge sharing between organizations as well as a lack of applying external knowledge in their organizations. As a result, they were required to spend a lot of money for in-house research and development. In addition, when unable to develop themselves, most companies bought a number of technologies and innovations to use in their organizations, which is considered a closed innovation. Since the Thai automotive parts manufacturers have created a very small number of innovations compared to other countries, it is necessary to accelerate the development of innovations by focusing on obtaining and using external knowledge to reduce development period and gain new knowledge. According to the research results, external knowledge source obtained from customers through their complaints and information of use problems was important and necessary for organization innovation. Thai automotive parts manufacturers can use this information to develop and improve their organization innovation. Moreover, according to the research results, most companies used a trial and error method starting from the operations of their employees to lead to the best practices of their organizations.
\end{abstract}

\section{Keywords}

Open Innovation Management, Auto Parts Manufacturer 


\section{Introduction}

The innovation of the organization partly represents the success and performance of such organization because it is based on knowledge that can be acquired through research, purchase or personnel's knowledge called "Best Practice". Organization innovation is part of the organization's success and performance. It can be divided into 4 types based on the purpose of utilization: [40]. 1) Product innovation is to develop and present a new product and technology or to improve existing products for better quality and efficiency. 2) Service innovation is to bring ideas or technologies into new practices to meet the needs and create customer satisfaction as well as to enhance efficiency and effectiveness of the services and create added value for the business. 3) Process innovation is to apply new knowledge in the production processes to be more efficient and flexible with low cost, which can reflect a matter of changes in the organization, including tools, manufacturing process, distribution or organization management style that aims to lead to the development of product innovation and to reach to the consumers or users with the most efficiency and effectiveness to the organization and 4) Management innovation is to respond to the new era of operations that may include the development of a new working system or practice or combinations, which all requires investment but the investment is sometimes wasted, such as investment in laboratory research and trial application of knowledge with no success. The traditional concept of innovation is that each business does it themselves, which is followed by a problem of redundancy and huge investment when it is viewed in the whole country. In addition, small companies cannot do this because they have no enough resources to create knowledge. Moreover, the traditional "closed innovation" also prevents every business that creates knowledge from disclosing or sharing its knowledge to other businesses to reduce the cost of acquiring such knowledge. With a changed perspective that successful business practices must be mutually friendly rather than competing each other so that every business can survive sustainably, the leading Japanese companies, such as Toyota and Fuji, have therefore invested in developing and sharing their knowledge, which is source of the common knowledge called "Relational Asset". However, this approach is still a closed system because knowledge is not shared with other non-venture businesses, but it is good for reducing innovation costs and for partnering in knowledge discovery. The innovation of the businesses in Thailand is very few in comparison with other countries, such as Japan or Korea, as shown in Table 1, and most of which are involved with artistic innovation, such as design of clothing, shoes, and gems.

Various changes make the organization have to compete for survival by using strategies of differentiation, cost leadership, or target-group focus, and each of which all relies on knowledge to support its innovation. In the manufacturing sector, the Thai automotive industry is targeted at low cost production, which is regarded as a process innovation, because this industry can create much value for Thailand as compared to other industries and it is one of the industries that 
focus on innovation development. In addition, the Thai automotive industry is seen as the strongest player because it has the largest number of 2500 entrepreneurs.

Therefore, to respond to government policies emphasizing the innovationbased industrial development and to increase capacity onto the world automotive stage, the automotive manufacturers are required to join in developing and acquiring the knowledge to support their process innovation.

\section{Literature Review}

Innovation problems in the businesses are often caused by inefficiency in managing their foundation of knowledge resources, which is the source of innovation, including lack of knowledge absorption and dissemination to others for further applications. As the traditional concept of "Closed Innovation", as shown in Figure 1 below, is an obstacle to create different styles of innovation combined with faster communication technology, the knowledge management for innovation has been expanded into the concept of "Open Innovation" in order to support small businesses to have knowledge with less investment used and to encourage the more effective creation of knowledge.

Table 1. Patent registration statistics in Thailand during 2012-2016.

\begin{tabular}{|c|c|c|c|c|c|}
\hline \multirow{2}{*}{ Year } & \multicolumn{5}{|c|}{ Granted Patent Registrations } \\
\hline & 2012 & 2013 & 2014 & 2015 & 2016 \\
\hline $\begin{array}{c}\text { Invention patents } \\
\text { Thailand }\end{array}$ & 39 & 52 & 67 & 62 & 61 \\
\hline $\begin{array}{l}\text { Invention patents } \\
\text { Other countries }\end{array}$ & 969 & 1097 & 1219 & 1302 & 1777 \\
\hline $\begin{array}{c}\text { Design patents } \\
\text { Thailand }\end{array}$ & 1173 & 1586 & 1455 & 2090 & 2103 \\
\hline $\begin{array}{l}\text { Design patents } \\
\text { Other countries }\end{array}$ & 934 & 1272 & 1022 & 1621 & 1652 \\
\hline $\begin{array}{c}\text { Total patents } \\
\text { Thailand }\end{array}$ & 1212 & 1638 & 1522 & 2152 & 2194 \\
\hline $\begin{array}{c}\text { Total patents } \\
\text { Other countries }\end{array}$ & 1903 & 2369 & 2241 & 2923 & 3429 \\
\hline
\end{tabular}

Source: 2016 Annual Report 2016, Department of Intellectual Property.

\begin{tabular}{|lc|} 
Research and Development & Best Practice \\
Trial and Error & Tacit Knowledge \\
Purchase & Internet Network \\
& Innovation \\
\hline
\end{tabular}

Figure 1. Closed innovation. 
The closed innovation as shown in Figure 1 starts with the use of ideas and knowledge of people in the organization, including trial and error, and research and development. These methods all require investment to expand the innovation into the market. This closed innovation is limited only to the knowledge of people in the organization and needs a high budget while it cannot be known whether the research results can be applied. In addition, the knowledge acquired cannot be disclosed to outside organizations and is sometimes not stored for further development.

\subsection{Open Innovation Management}

A key principle of open innovation management is about learning from both inside and outside the organization, both formal and informal, to create knowledge for innovation, as shown in Figure 2 below.

The open innovation as shown in Figure 2 starts with the application of ideas and knowledge of people in the organization as well as new ideas from external organizations. The organization does not need to start from its own research and development and may obtain knowledge through co-research, purchase of copyrights, knowledge transfer of between companies in the industry or between the industry and the universities, application of knowledge from the open sources or social media, and cooperation between organizations that have a business relationship to integrate internal and external research and development practices, which complements the open innovation process to create new products, technologies, and production processes into the market [1].

The open innovation can reduce the time of invention so the organization can spend most of its time to discover "innovative business model". As a result, the private sector has been strengthened at the industry level with worthiness for investment and the businesses can therefore compete to respond to the strategies

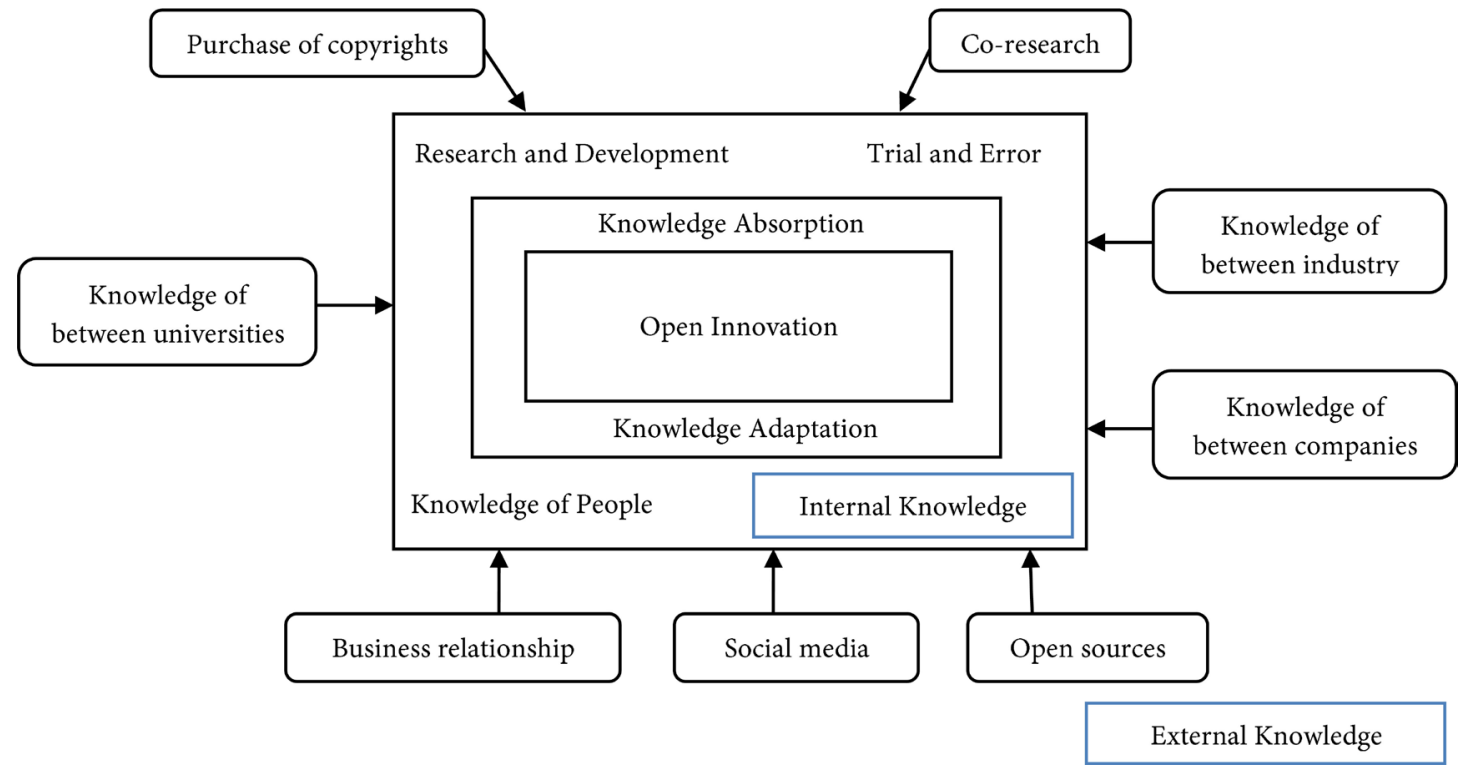

Figure 2. Open innovation. 
of the country to change from economic structure driven by the development of industrial production efficiency to the technology- and innovation-driven economy in order to increase the competitiveness of the domestic industry.

\subsection{Internal and External Sources of Knowledge}

Since the current sources of knowledge often consist of more components (i.e., new products and processes are often based on various technologies and sciences), it is important to understand that current companies are almost unable to separate learning and innovation from one another [2] [3] while most information and knowledge are still conveyed to their interrelated sections and departments, such as research and development, production, and marketing departments [4]. In the present context, it is increasingly necessary to rely on external sources of knowledge. Therefore, the sources of knowledge can be divided into two groups: internal and external sources of knowledge. External sources of knowledge can also be further subdivided into local, national and international sources of knowledge (based on their location) [5]. For internal sources of knowledge, the company will seek knowledge through its own research and development activities as well as through continuous process improvement. In addition, the skills of employees are also another important source of knowledge and the company often plans to educate and train its personnel in the company in order to build and develop its own knowledge base effectively. In case the company does not have proper knowledge within its organization, it is still able to seek outside knowledge by collaborating with its customers, suppliers, and other companies or with government, semi-governmental, and other private agencies. In terms of geographical location, these external agencies may refer to agencies located in the neighborhood (local sources of knowledge, in a particular area within the country (national sources of knowledge), or anywhere in the world (international sources of knowledge). It can be said that external sources of knowledge are involved with cooperation between companies, which is a practice that has been most interested in research studies. It is generally accepted that the innovation process is often related to the interaction between the manufacturers and the users, and this interaction is not only a matter of exchanging technical knowledge but also serves as important information about the needs and trends of the market. Moreover, another important source of knowledge comes from the other side of the supply chain: material suppliers [6] can provide essential knowledge to production, logistics and other departments of the company, but this cooperation between the companies is far more than the relationship between the business partners in the supply chain. According to the research with successful companies, there is always one type of partnership or cooperation between business partners or between the competitors. For example, the research in Cambridge shows that $76 \%$ of all companies are closely related to other companies [7]. When they analyzed the features of collaboration between the companies, they found that everything comes from joint venture, sub-contract, and re- 
search collaboration, and each of which exchanges or shares their equipment and customer information. Accordingly, we see that both vertical and horizontal relationships between companies are important external sources of knowledge and interactive learning [8] [9] [10].

The exchange of knowledge not only occurs between the companies but also between the company and other agencies. Universities, research institutes, science parks, laboratories, and other institutions of knowledge are all related in the business environment [11] and are often viewed as key players in the innovation activities of companies that provide input for scientific research to various companies [12]. In addition to providing information and knowledge, these support agencies can also translate technical knowledge into practical and accessible knowledge. The modern understanding of innovation believes that the current research process focuses on problem solving and it is therefore necessary to have a two-way interaction during research between the knowledge-based organizations and the industrial organizations, including other agencies [13].

The cooperation between the companies (including cooperation between the company and other agencies) has long been viewed as mainly limited to local cooperation and often researched only within a group context. However, in the age of globalization with the advancement of information technology and communication, the geographic scope of this interaction has expanded increasingly and often crosses the international boundaries. In case the company wants to succeed in innovation, it must have access to the highest level of technical knowledge in its industry. This means that the company must seek the right knowledge no matter where the knowledge is located in the world. Utilizing geographically close sources of knowledge has several advantages, such as face-to-face interaction, great flow of knowledge, and transfer of tacit knowledge [8] [12] [14]. However, it does not mean that the use of local knowledge is sufficient to create knowledge and innovation. According to the research, limiting the scope of knowledge acquisition at local level can lead to knowledge blockage [12] [15]. To maintain the continuous flow of new knowledge, the company needs to maintain relationships that exist both inside and outside its own group.

\subsection{Role of Sources of Knowledge towards the Company's Innovation Performance}

Research and development activities within the organization have been clearly proven as important for the company's innovation potential. Management members and other employees within the company are people who play an important role in the creation of knowledge and innovation [16]. In addition, the company's in-house research and development expertise has a tremendous impact on its ability of knowledge absorption, which is defined as "company's ability to appreciate new knowledge from the outside, absorb such knowledge, and apply such knowledge commercially" [17]. Accordingly, it means that continuous improvement of its own knowledge base is also important for enhancing company's ability of absorbing and changing external knowledge and information as its 
new products, services, and processes [18]. In addition, it is said that good internal knowledge base is the key to successful innovation. From this statement, we can therefore conclude that the more the internal sources of knowledge from within the company are utilized, the more the company can create innovation, utilize external sources of knowledge, and transform such knowledge into innovation.

At present, the companies in various industries are facing a constantly changing environment in terms of market, technology, and structure of the industry. In response to these uncertainties, many companies have more utilized external sources of knowledge. In addition, they still need to strengthen their own knowledge base by combining knowledge of other companies and agencies with its own knowledge base (often in any form of collaboration) so that they can utilize their own knowledge more effectively. The increased importance of this collaboration between the organizations can be explained by the concept of "modern knowledge" [19]. This concept suggests that creating new knowledge may be very expensive, the results of the huge investment to increase knowledge (through research and development) are very uncertain, knowledge in various fields can quickly become obsolete, and complex problems must be addressed by experts in various fields. In addition, the current competitive pressures are constraining companies to bring their new products and services into the market faster, and many companies (especially small and medium companies) are impossible to rely solely on their own internal resources to create the necessary knowledge. Accordingly, the result is that at present there are several companies and agencies have joined a between-agencies collaboration project [20]. Therefore, it is evident that what these theories say consistently is that external sources of knowledge are an important support for learning and innovation within the company as well as contribute to the efficiency of innovation performance [21].

\subsection{Customer Knowledge Co-Creation}

Nowadays, customer knowledge is becoming an essential abstract asset for companies because it enables these companies to create and customize their value proposition [22]. In addition, customer knowledge is often seen as a means of achieving long-lasting competitive advantage in the near future [23]. It is said that the benefits of getting customers to participate in value creation are that new products and innovations can be developed and created with a lower cost, customers accept new products increasingly, and customers are more willing to buy new products and appreciate the value of their newness [24]. The best value for the customers can be created by combining customer knowledge with the market knowledge to make sure that the company will be able to maximize profitability and flexibility in its operations [23].

Customer knowledge (deeply embedded in the relationship with the customers) can directly and indirectly affect the way in which the company operates [25]. We may divide knowledge into categories (most popular in previous stu- 
dies): knowledge about customers, knowledge for customers, and knowledge from customers [26] [27] [28]. It can be said that the collection and processing of information about customers is one of the oldest activities related to knowledge management, especially customer relation management. In addition, this kind of knowledge (in addition to basic information about customers) consists of information regarding requirements, desires, chosen communication methods, financial ability, and buying behavior of customers both in the present and future [29] [30]. Knowledge about customers obtained by the company will be further supported by information obtained from other agencies (generally in the form of commercial information). Knowledge from customers consists of observations, ideas, insights, or information, which are voluntarily communicated to a company, and may be collected from the questionnaire-based survey, inquiry or observation of customer behavior. It is recommended that this information should be used in an innovative process (e.g. used to create new ideas) or used to improve existing products and services [31]. It is said that above-mentioned classification of the knowledge should be made more complete by including customer knowledge (sometimes referred to as "knowledge co-creation") where customers engage in knowledge creation. This co-created knowledge is involved with knowledge used in developing new products or services and is based on discussions and cooperation with the company where appropriate tools and methods will be used to promote the more effective interaction and knowledge creation [32]. Customers are seen as a member of a value network and they collaborate with the company to create value. This knowledge co-creation process is affected both by customers and by the company [33]. In customer's view, key factors include the ability to support and stimulate knowledge creation and customer confidence with the company, while the company should also have necessary resources and capabilities to absorb, share and keep knowledge appropriately within its organization.

\section{Research Methodology}

This research began with the literature review from relevant databases together with qualitative research through in-depth interviews with those involved in research and development in five automotive manufacturing companies in Thailand. The names of these companies were represented by letters A to E. We developed an interview form which consists of topics and open-ended questions used in the interviews. In addition, there was a small-group meeting with experts in the automotive industry to examine, test, improve or revise the interview form for effective use selected automotive parts manufacturing companies in order to know what sources of knowledge that those companies used from.

\subsection{Data Collection}

The researchers conducted in-depth interviews with senior executives who are involved in research and development in five companies selected from the 2017 
automotive industry record. These companies manufacture and provide automotive parts to original equipment manufacturers (OEMs) directly and were selected to represent the automotive industry in order to know the sources of knowledge within the organization. They represented the manufacturers of different automotive parts: 1) exterior and body parts, 2) interior parts, 3) engine parts, 4) drive and transmission parts, and 5) suspension and brake parts, in order to know the internal sources of knowledge that are diverse and cover all product segments of automotive parts.

\subsection{Scope of the Research}

The scope of the interviews covered the following topics: 1) what sources of knowledge are used in the organization, 2) what percentage of sources of knowledge is used in the organization, and 3) what problems are found from such sources of knowledge. The researchers spent an average of one hour for each interview and the interviews were recorded and transcribed for further analysis.

\subsection{Data Analysis}

After gathering data from in-depth interviews, We analyzed the data by taking into knowledge obtained from the interviews to determine the common factors. The sources of knowledge were then classified as internal and external sources of knowledge and analyzed to understand the process of creating new knowledge of the organization.

\section{Results}

From the data collected from five companies, the overall sources of knowledge used in the organization to create open innovation of the Thai automotive industry currently operating in the country (2018) can be summarized as follows:

\subsection{Analysis of Total Sources of Knowledge Obtained from the Study of Sample Companies}

Based on the analysis results as shown in Figure 3, the top two sources of knowledge were in-house research and development and joint with customer, respectively. In the new marketing dimension, the customer co-creation comes from customer complaints and experiences. The third and forth sources of knowledge were trial and error that usually become correct knowledge and are later used as best practice, respectively.

\subsection{Ratio Analysis of Sources of Knowledge Used in the Automotive Industry}

Based on the total sources of knowledge used by five companies as shown in Figure 4, the least two sources of knowledge used in the automotive industry were joint with university and joint with government, respectively. Therefore, these 


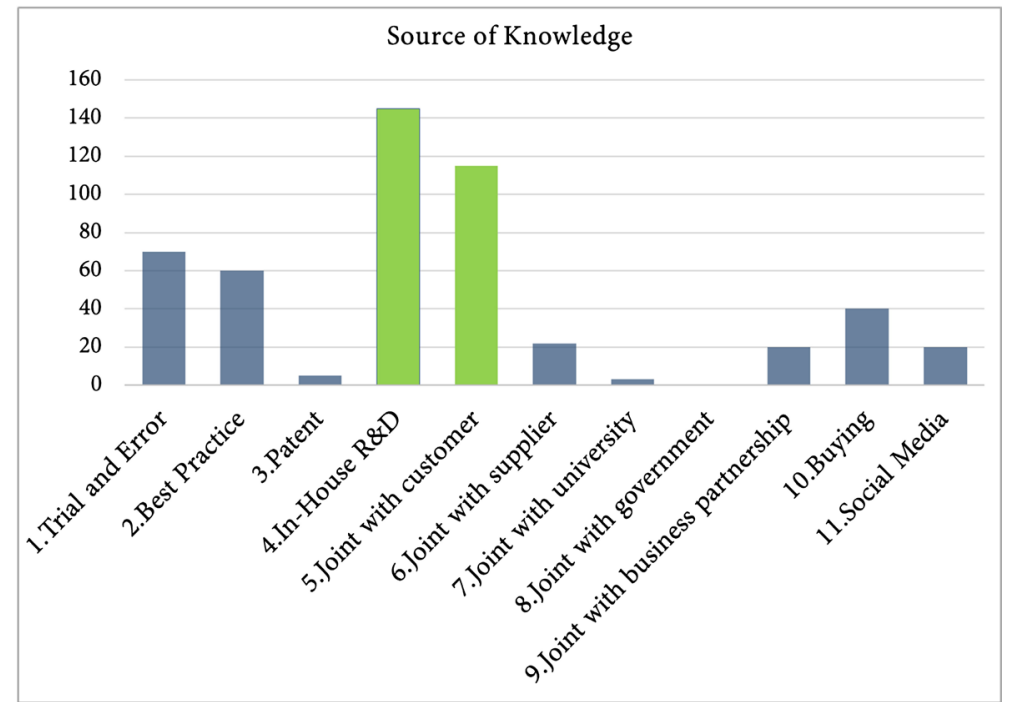

Figure 3. Total sources of knowledge obtained from five sample automotive companies.

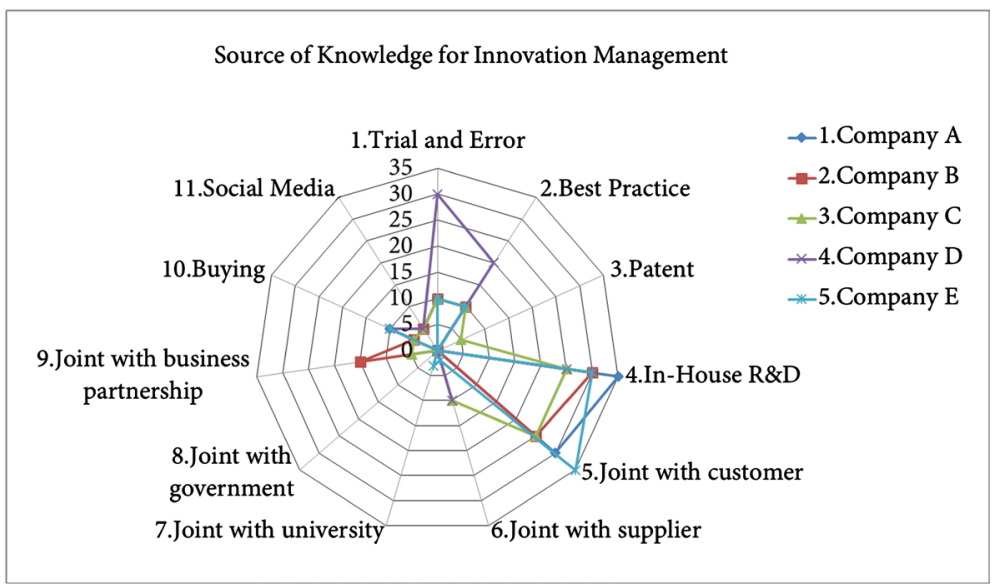

Figure 4. Ratio analysis of sources of knowledge used in the automotive industry.

companies had a high cost and took a long time for their own research and development activities because their employees had their own jobs and thus spent less time on research and development.

\subsection{Analysis of Sources of Knowledge Obtained from This Study}

By considering all eleven sources of knowledge obtained from this study and used in the automotive industry, the results of the analysis show that the sources of knowledge can be divided into two groups:

Group 1. Internal Sources of Knowledge

The results of this study indicated that the internal sources of knowledge of Companies A to E were all composed of four sources of knowledge as shown in Figure 5. Knowledge source 1 comes from employee's learning by self-practice and trial and error until the new knowledge has occurred in the persons. Knowledge source 2 is mainly the knowledge of practitioners who have learned through working until they have obtained the best practices. Knowledge source 3 
comes from a fact that the company has bought and applied a patent that is related to the specialized production processes to its own production processes. Finally, knowledge source 4 comes from the research and development in their own companies, such as research and development of material forming processes for use in the production of auto parts.

\section{Group 2. External Sources of Knowledge}

The results of this study indicated that the external sources of knowledge of Companies A to E were all composed of seven sources of knowledge as shown in Figure 6 below.

\subsection{Analysis of Quantity of Knowledge Obtained from Trial and Error and Best Practice in Five Sample Companies}

The results of the study found that the best practice was often created by employees working in the production department. Therefore, if knowledge is sought through trial and error and the best practice is then created, it means that the knowledge gained through this method is almost retained, which represents

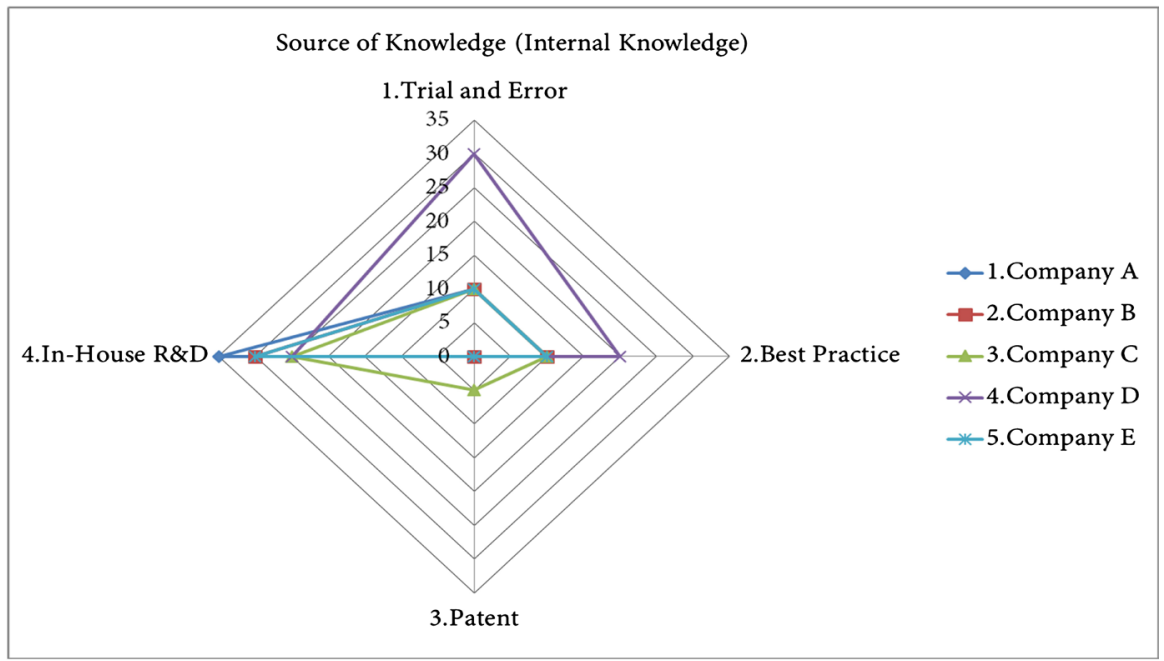

Figure 5. Internal sources of knowledge.

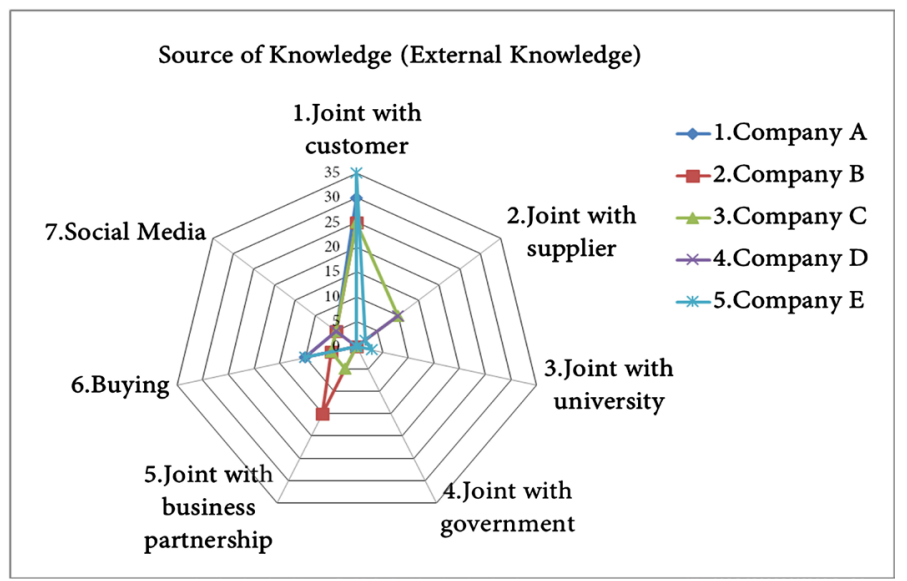

Figure 6. External sources of knowledge. 
the effectiveness of knowledge management in terms of knowledge creation and knowledge storing. This can be seen in the companies' information shown in Figure 7 below; except for the fourth company that had a knowledge retention rate of only $67 \%$ (knowledge was sought through trial and error at $30 \%$ but through best practice at $20 \%$ only).

Since the theoretically obtained knowledge must be often adapted to the different environments and factors of production in each area, it can be seen that, in most cases, the knowledge creation process is usually as shown in Figure 8 below.

\section{Discussion and Conclusions}

According to the results of the study in item A, the two most common sources of knowledge used by companies in the automotive industry were discovered, and the highest source of knowledge was in-house research and development. If every company in the automotive industry performs its research and development activities itself, they will face higher costs; therefore, it is recommended to encourage the sharing of knowledge to reduce costs and time. Knowledge sharing



Figure 7. Quantity of knowledge obtained from trial and error and best practice in five sample companies.

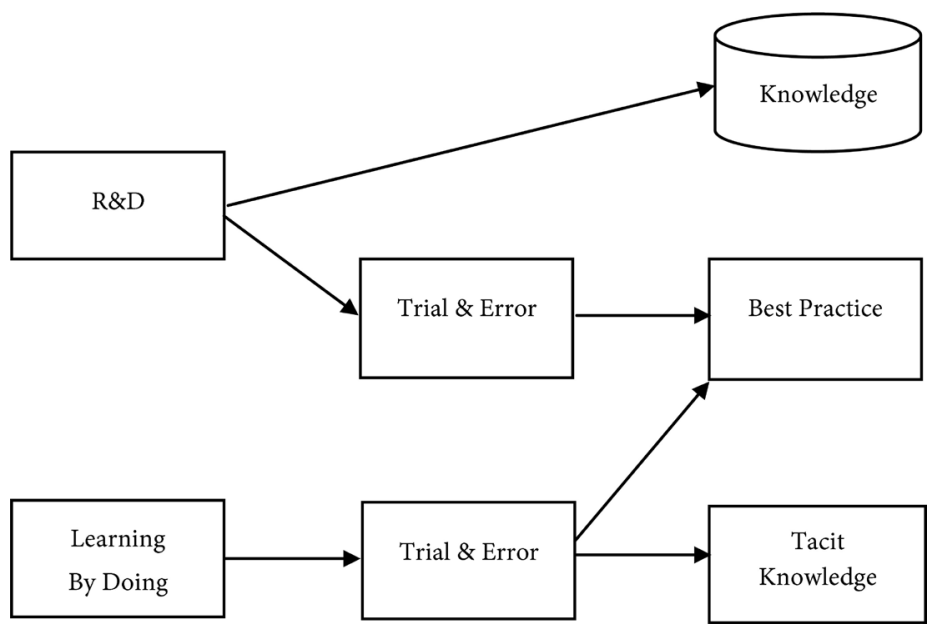

Figure 8. Process of new knowledge creation from original knowledge in the organization. 
between companies can occur, but it is difficult in practice because most companies are business competitors to each other. So, the company should consider other industries with the same desired knowledge and then exchange their knowledge in order to lead to the development of the automotive industry. According to Danial and Alexander, the knowledge management within the same organization or cluster is inadequate and cannot respond to all aspects. Thus, it is recommended to exchange the same knowledge with other industries or clusters to lead to the absorption and adaptation of knowledge and eventually the development of open innovation [34].

The second source of knowledge was joint with customer. The new marketing dimension is involved with a concept of customer co-creation based on customer complaints and experiences. According to HA Smith and J. McKeen, the knowledge should be made more complete by including customer knowledge, which is referred to as "knowledge co-creation") where customers engage in knowledge creation [32]. Nowadays, customer knowledge is becoming an essential abstract asset for companies because it enables these companies to create and customize their value proposition [22]. In addition, customer knowledge is often seen as a means of achieving long-lasting competitive advantage in the near future [23]. The benefits of getting customers to participate in value creation are that new products and innovations can be developed and created with a lower cost, customers accept new products increasingly, and customers are more willing to buy new products and appreciate the value of their newness [24]. The company should also have necessary resources and capabilities to absorb, share and keep knowledge appropriately within its organization [33].

According to the results of the study in item B, the least two sources of knowledge used in the automotive industry were joint with university and joint with government, respectively. Therefore, these companies had a high cost and took a long time for their own research and development activities and for acquiring new knowledge because their employees had no research skills. Some research suggested that there should be a network of cooperation between the organization and other institutions, such as universities, technology organizations, or research institutes, to provide research assistances for successful development of innovation [35]. In addition, some opined that an effective way to promote innovation is that both public and private sectors should cooperate to each other [36]. The government should also set up institutions that focus on cultivating and driving the innovation so that those who graduated from these institutions have modern knowledge of innovation development [37]. Furthermore, a cluster network should be established to focus on developing the innovation so that the resources are shared to creative, design and produce innovative products. As a result, the costs and time spent on research and development by companies in the automotive industry can be minimized [38].

According to the results of the study in item $\mathrm{C}$, the companies in the automotive industry used both internal and external sources of knowledge for their de- 
velopment. This is in line with previous research suggesting that from an innovation perspective, new knowledge not only occurs in the research and development department, but it also is relevant to the company's general manufacturing activities and other factors, including through a process of interactive learning from the outside of the organization, before the innovation is developed [20]. When the company will develop new products and services or improve its production process, it must cooperate with suppliers, customers, knowledgeable agencies, universities, labs, etc. [39] and may even collaborate with its own competitors. The process of innovation must be viewed as a flow of knowledge both within the organization itself and in the relationship between the organization and the external environment.

Finally, according to the results of the study in item $\mathrm{D}$, it can be seen that if knowledge is sought through trial and error and the best practice is then created, it means that the knowledge gained through this method is almost retained, which represents the effectiveness of knowledge management. Therefore, the researchers present a process of new knowledge creation from original knowledge in the organization, as shown in Figure 8, to be applied in the automotive companies.

\section{Future Research}

The results of this study through in-depth interviews found a similar problem in sample companies regarding the mutual exchange of knowledge between employees from both external and internal sources of knowledge. With different educational levels, abilities in foreign languages, communications, and experience, employees cannot completely apply the knowledge they learnt and obtained because their ability to understand and absorb external sources of knowledge is not good enough so they cannot fully apply these external sources of knowledge. Therefore, future research should examine the mechanism of developing personnel's ability of knowledge absorption so that they can adapt external knowledge and create open innovation in the automotive industry.

\section{Limitations in This Research}

However, the companies chosen by us for interviews in this study were tier-1 suppliers that deliver parts to the car assembly companies directly and most of which are large companies. We did not select tier- 2 and tier-3 suppliers and most of which are medium and small companies; therefore, this study did not cover the entire supply chain of the automotive industry. According to the consideration, it was found that the different orders of delivery of automotive parts might result in the different abilities of organization innovation. As a result, We suggests that the next study should focus on small-and medium-sized automotive parts manufacturing companies because there are approximately 2500 companies in Thai automotive industry in order to know the problems and solutions to develop the entire Thai automotive industry. 


\section{Conflicts of Interest}

The authors declare no conflicts of interest regarding the publication of this paper.

\section{References}

[1] Chesbrough, H. (2004) Managing Open Innovation. Research Technology Management, 47, 23-26. https://doi.org/10.1080/08956308.2004.11671604

[2] Pavitt, K. (1998) Technologies, Products and Organization in the Innovating Firm: What Adam Smith Tells Us and Joseph Schumpeter Doesn't. Industrial and Corporate Change, 7, 433-452. https://doi.org/10.1093/icc/7.3.433

[3] Johnson, B. (2002) Why All This Fuss about Codified and Tacit Knowledge? Industrial and Corporate Change, 11, 245-262. https://doi.org/10.1093/icc/11.2.245

[4] Capello, R. (1999) Spatial Transfer of Knowledge in High Technology Milieux: Learning versus Collective Learning Processes. Regional Studies, 33, 353-365. https://doi.org/10.1080/00343409950081211

[5] Belussi, F. (2002) Industrial Districts: State of the Art Review. Research Report, Project West-East id: Industrial Districts Re-Location Processes; Identifying Policies in the Perspective of the European Union Enlargement.

[6] Geenhuizen, M. (1997) A Microscopic View on Spatial Innovation: The Case of the Nether lands in the Dynamics of Innovative Regions, 265-277.

[7] Keeble, D. (1999) Collective Learning and Knowledge Development in the Evolution of Regional Clusters of High-Technology Smes in Europe. Regional Studies, 33, 295-303. https://doi.org/10.1080/00343409950081167

[8] Camagni, R. (1991) Local Milieu, Uncertainty and Innovation Networks: Towards a New Dynamic Theory of Economic Space. In: Camagni, R., Ed., Innovation Networks: Spatial Perspective, 121-143.

[9] Yeung, H.W.C. (2005) The Firm as Social Networks: An Organizational Perspective. Growth and Change, 36, 307-328. https://doi.org/10.1111/j.1468-2257.2005.00279.x

[10] Steiner, M. (2006) Organizational Learning in Clusters: A Case Study on Material and Immaterial Dimensions of Cooperation. Regional Studies, 40, 493-506. https://doi.org/10.1080/00343400600757494

[11] Gunasekara, C. (2006) The Generative and Developmental Roles of Universities in Regional Innovation Systems. Science and Public Policy, 33, 137-150. https://doi.org/10.3152/147154306781779118

[12] Keeble, D. (2000) Collective Learning Processes in European High-Technology Milieux. In: High Technology Clusters, Networking and Collective Learning in Europe, 199-229.

[13] Gambarotto, F. (2004) The Role of Reconnection of Competencies and Institutions in the Collective Learning Process. http://www.eco.unipmn.it/eventi/eadi/papers/gambarottosolari.pdf

[14] Capello, R. (2005) Collective Learning and Relational Capital in Local Innovation Processes. Regional Studies, 39, 75-87. https://doi.org/10.1080/0034340052000320851

[15] Grabher, G. (1993) The Embedded Firm: On Socioeconomics of Industrial Networks. Routledge, London.

[16] Thorpe, R. and Holt, A. (2005) Using Knowledge with Small and Medium-Sized Firms: A Systematic Review of the Evidence. International Journal of Management 
Reviews, 7, 257-281. https://doi.org/10.1111/j.1468-2370.2005.00116.x

[17] Cohen, W.M. and Levinthal, A. (1990) Absorbtive Capacity: A New Perspective on Learning and Innovation. Administrative Science Quarterly, 35, 128-152. https://doi.org/10.2307/2393553

[18] Lundvall, B.A. (1999) Competition and Transformation in the Learning Economy: The Danish Case. Revue d Economie Industrielle, 88, 67-90. https://doi.org/10.3406/rei.1999.1745

[19] Dunning, J. (2000) Regions, Globalization and the Knowledge-Based Economy. Oxford University Press, New York.

[20] Eriksson, M.L. (2005) Organizing Regional Innovation Support: Sweden's Industrial Development Centres as Regional Development Coalitions. PHD Diss., Linköping University.

[21] Caloghirou, Y. (2004) Internal Capabilities and External Knowledge Sources: Complements or Substitutes for Innovative Performance? Technovation, 24, 29-39. https://doi.org/10.1016/S0166-4972(02)00051-2

[22] Rowley, J. (2002) Eight Questions for Customer Knowledge Management in eBusiness. Journal of Knowledge Management, 6, 500-511. https://doi.org/10.1108/13673270210450441

[23] Claycomb, C., Dröge, C. and Germain, R. (2005) Applied Customer Knowledge in a Manufacturing Environment: Flexibility for Industrial Firms. Industrial Marketing Management, 34, 629-640. https://doi.org/10.1016/j.indmarman.2004.10.008

[24] Reichwald, R. and Piller, F. (2006) Interactive Wertsschpfung. Open Innovation, Individualisierung und neue Formen der Arbeitsteilung, Gabler, Wiesbaden.

[25] Zanjani, M.S., Rouzbehani, R. and Dabbagh, H. (2008) Proposing Conceptual Model of Customer Knowledge Management: A Study of CKM Tools in British Dotcoms. Word Academy of Science, Engineering and Technology, 2, 51-55.

[26] Garcia, M. and Annabi, H. (2002) Customer Knowledge Management. Journal of the Operational Research Society, 53, 875-884.

[27] Gebert, H., Geib, M., Kolbe, L. and Brenner, W. (2003) Knowledge-Enabled Customer Relationship Management: Integrating Customer Relationship Management and Knowledge Management Concepts. Journal of Knowledge Management, 7, 107-123. https://doi.org/10.1108/13673270310505421

[28] Salomann, H., Dous, M., Kolbe, L. and Brenner, W. (2005) Rejuvenating Customer Management: How to Make Knowledge for, from and about Customers Work. European Management Journal, 23, 392-403.

[29] Day, G.S. (2000) Capabilities for Forging Customer Relationships. Marketing Science Institute, Cambridge.

[30] Davenport, T.H., Harris, J.G. and Kohli, A.K. (2001) How Do They Know Their Customers So Well? MIT Sloan Management Review, 42, 63-73.

[31] Thomke, S. and Hippel, E. (2002) Customers as Innovators: A New Way to Create Value. Harvard Business Review, 80, 74-81.

[32] Smith, H.A. and McKeen, J.D. (2005) Developments in Practice XVIII-Customer Knowledge Management: Adding Value for Our Customers. Communications of the Association for Information Systems, 16, Article 36.

https://doi.org/10.17705/1CAIS.01636

[33] Sawhney, M. and Prandelli, E. (2000) Beyond Customer Knowledge Management: Customers as Knowledge Co-Creators. Knowledge Management and Virtual Organizations, Idea Group Publishing. 
https://doi.org/10.4018/978-1-930708-65-5.ch014

[34] Daniel, P. and Alexander, P. (2005) Cross Company Knowledge and Human Resource Management in Technology Clusters. School of Mathematics and System Engineering, 1-47.

[35] Xie, X.M., Zeng, S.X. and Tam, C.M. (2010) Overcoming Barriers to Innovation in SMEs in China: A Perspective Based Co-Operation Network. Innovation: Management, Policy \& Practice, 12, 298-310.

[36] Hadjimanolis, A. (1999) Barriers to Innovation for SME in a Small Less Developed Country (Cyprus). Technovation, 19, 561-570.

https://doi.org/10.1016/S0166-4972(99)00034-6

[37] Sabir, R.I. and Sabir, R.M. (2010) Managing Technological Innovation: China's Strategy and Challenges. Journal of Technology Management in China, 5, 213-226. https://doi.org/10.1108/17468771011086238

[38] McAdam, R., McConvery, T. and Armstrong, G. (2004) Barriers to Innovation within Small Firms in a Peripheral Location. International Journal of Entrepreneurial Behaviour \& Research, 10, 206-221.

https://doi.org/10.1108/13552550410536780

[39] Santos, D. (2000) Innovation and Territory: Which Strategies to Promote Regional Innovation Systems in Portugal? European Urban and Regional Studies, 7, 147-157. https://doi.org/10.1177/096977640000700204

[40] Damanpour, F., Walker, R.M. and Avellaneda, C.N. (2009) Combinative Effects of Innovation Types and Organizational Performance: A Longitudinal Study of Service Organizations. Journal of Management Studies, 46, 650-675. https://doi.org/10.1111/j.1467-6486.2008.00814.x 